\title{
Kinerja probiotik Bacillus sp. pada pendederan benih ikan lele Clarias sp. yang diinfeksi Aeromonas hydrophila
}

\section{Performance of Bacillus sp. probiotic in catfish juvenile Clarias sp. infected by Aeromonas hydrophila}

\author{
Sukenda*, Muhammad Mufthi Rafsyanzani, Rahman, Dendi Hidayatullah \\ Departemen Budidaya Perairan, Fakultas Perikanan dan Ilmu Kelautan, Institut Pertanian Bogor \\ Kampus IPB Dramaga Bogor, Jawa Barat 16680 \\ *Surel: sukenda67@gmail.com
}

\begin{abstract}
This experiment was conducted to assess performance of Bacillus sp. probiotic on catfish juvenile Clarias sp. infected by Aeromonas hydrophila. The probiotic content in the diets were $0 \%(\mathrm{~K}+$ and $\mathrm{K}-), 1 \%$, and $2 \%$ in duplicates. This experiment used randomized design with four treatments and two replications. Juveniles with average body weight of $3.22 \pm 0.15 \mathrm{~g} /$ fish were reared in the $1.5 \times 2.8 \times 0.5 \mathrm{~m}^{3}$ pond with density of $800 \mathrm{fish} /$ pond. Fish were reared for 30 days and fed three times a day at rate $8 \%$ of total body weight. At day 31, catfish were challenged by A. hydrophila $0.1 \mathrm{~mL}$ $\left(10^{6} \mathrm{cfu} / \mathrm{mL}\right)$. Post infection observation was carried out ten days with density $10 \mathrm{fish} /$ aquaria. The result showed that fish fed diet containing $2 \%$ probiotic gave the best probiotic performance with survival rate of catfish $83.33 \%$ after challenged, spesific growth rate $5.40 \%$, and 0,75 of feed conversion ratio. The results of the blood profile showed significantly better results in the treatment of probiotics compared to the positive control after challenge test $A$. hydrophila. Probiotic Bacillus sp. has given as much as $2 \%$ on feed provides better performance on catfish juvenile.
\end{abstract}

Keywords: probiotic, Bacillus sp., Aeromonas hydrophila, catfish juvenille, growth

\begin{abstract}
ABSTRAK
Penelitian ini bertujuan untuk menguji kinerja probiotik Bacillus sp. dalam pakan pada pendederan benih ikan lele Clarias sp. yang diinfeksi bakteri Aeromonas hydrophila. Penelitian ini menggunakan rancangan acak lengkap dengan empat perlakuan yaitu kandungan probiotik dalam pakan perlakuan yaitu $0 \%(\mathrm{~K}+\mathrm{dan} \mathrm{K}-), 1 \%$, dan $2 \%$, masing-masing dengan dua ulangan. Ikan lele yang digunakan memiliki bobot rata-rata 3,22 $\pm 0,15 \mathrm{~g} /$ ekor, dipelihara dalam kolam terpal berukuran $1,5 \times 2,8 \times 0,5 \mathrm{~m}^{3}$ dengan kepadatan 800 ekor/kolam. Ikan dipelihara selama 30 hari dengan frekuensi pemberian pakan tiga kali sehari sebanyak $8 \%$ dari bobot tubuh ikan. Hari ke-31 benih lele diinjeksi bakteri A. hydrophila dosis $0,1 \mathrm{~mL} / \mathrm{ekor}$ dengan kepadatan bakteri $10^{6} \mathrm{cfu} /$ $\mathrm{mL}$. Pemeliharaan setelah diinfeksi dilakukan selama sepuluh hari dengan kepadatan 10 ekor/akuarium. Hasil penelitian menunjukkan ikan yang diberi probiotik $2 \%$ memperlihatkan kinerja probiotik terbaik dengan tingkat kelangsungan hidup ikan lele sebesar 83,33\% setelah diinfeksi dengan A. hydrophila; laju pertumbuhan harian sebesar 5,40\%; dan konversi pakan 0,75. Hasil gambaran darah menunjukkan hasil yang signifikan lebih baik pada perlakuan pemberian probiotik dibandingkan kontrol positif pascauji tantang A. hydrophila. Probiotik Bacillus sp. yang diberikan sebanyak $2 \%$ pada pakan memberikan kinerja lebih baik pada pendederan benih ikan lele.
\end{abstract}

Kata kunci: probiotik, Bacillus sp., Aeromonas hydrophila, benih lele, pertumbuhan

\section{PENDAHULUAN}

Ikan lele merupakan komoditas ikan air tawar yang banyak diminati di Pulau Jawa dan sekitarnya. Permintaan pasar yang tinggi menarik minat para pembudidaya untuk membudidayakan ikan lele. Ikan lele juga termasuk salah satu komoditas air tawar unggulan Kementerian
Kelautan dan Perikanan (KKP) untuk ditingkatkan produksinya. Produksi ikan lele pada tahun 2013 mencapai 543.774 ton dan meningkat pada tahun 2014 menjadi 613.119 ton (KKP, 2014).

Salah satu kendala penyakit yang sering menyerang budidaya ikan lele adalah motile aeromonad septicemia (MAS). Penyakit tersebut disebakan oleh agen bakteri Aeromonas 
hydrophila. Bakteri A. hydrophila adalah bakteri gram negatif berbentuk batang dan menyerang ikan saat kondisi lingkungan yang kurang baik (Yu et al., 2004). Upaya pengendalian penyakit menggunakan antibiotik sudah banyak dilarang. Penggunaan antibiotik dapat menyebabkan terjadinya resistensi bakteri terhadap jenis antibiotik tersebut (Azhar, 2013). Selain itu sisa-sisa antibiotik pada ikan komersial yang tidak terdeteksi tersebut dapat menyebabkan terjadinya alergi dan keracunan yang dapat merugikan para konsumen (Cabello et al., 2006).

Probiotik merupakan agen mikrob hidup yang memberikan keuntungan terhadap inangnya dengan cara memodifikasi komunitas mikrob atau berasosiasi dengan inangnya, meningkatkan respons terhadap penyakit, memperbaiki nutrisi, dan pemanfaatan pakan (Nayak, 2010). Probiotik memiliki sifat meningkatkan efisiensi pakan serta meningkatkan imun nonspesifik pada ikan. Pemberian probiotik ini memungkinkan ikan mencapai pertumbuhan optimal dan meningkatkan imunitas terhadap penyakit (Utami et al., 2015; Talpur et al., 2015).

Beberapa studi menunjukkan bahwa pemberian probiotik dapat meningkatkan sintasan udang (Widanarni et al., 2008; Zang et al., 2014), konversi pakan ikan nila (Marzouk et al., 2008), sistem imun ikan mas (Septiarini, 2012), dan efisiensi pakan pada ikan patin (Setiawati et al.,2013). Kelompok bakteri yang dapat menjadi kandidat probiotik adalah LactoBacillus sp., Photobacterium sp., dan Bacillus sp. Beberapa hasil penelitian menunjukkan bahwa penggunaan bakteri Bacillus sp. sebagai probiotik telah mampu meningkatkan pertumbuhan udang (Febrianti et al., 2015) dan ikan (Soedibya, 2013; Putra et al., 2015). Oleh karena itu, pada penelitian ini digunakan probiotik komersil dengan kandungan bakteri Bacillus sp. Penelitian ini bertujuan untuk menguji efektifitas kinerja probiotik Bacillus sp. pada pendederan ikan lele sebagai upaya pencegahan infeksi A. hydrophila pada ikan lele Clarias sp.

\section{BAHAN DAN METODE}

\section{Persiapan wadah dan ikan uji}

Wadah yang digunakan adalah kolam terpal berukuran $1,5 \times 2,8 \times 0,5 \mathrm{~m}$ dan akuarium berukuran $90 \times 50 \times 40 \mathrm{~cm}$. Persiapan wadah yang dilakukan meliputi pencucian kolam dan pengisian dengan air tandon yang sudah diendapkan. Air kolam didesinfeksi dengan virkon 1,2 ppm dan dibiarkan selama satu hari. Ikan lele yang digunakan memiliki bobot rata-rata $3,22 \pm 0,15$ g. Ikan uji yang telah diadaptasikan pada kolam terpal. Pemeliharaan tidak menggunakan sistem aerasi, dan dilaksanakan di tempat terbuka. Kualitas air selama pemeliharaan ikan lele pada suhu 25-30 ${ }^{\circ} \mathrm{C} ; \mathrm{pH}$ 7,4-7,5; kelarutan oksigen 3,9-5,4 mg/L; amonia $0,009 \mathrm{mg} / \mathrm{mL}$. Kepadatan ikan uji pada setiap kolam adalah 800 ekor/kolam. Selanjutnya untuk uji tantang ikan uji yang dipelihara diambil secara acak sebanyak 10 ekor setiap perlakuan kemudian diadaptasikan pada akuarium dan dipuasakan selama satu hari.

\section{Pencampuran pakan dengan probiotik dan pemeliharaan ikan uji}

Probiotik yang digunakan adalah probiotik komersil dengan kandungan Bacillus sp. Pakan komersial yang digunakan memiliki kandungan protein 38\%. Probiotik dicampurkan ke dalam pakan komersil sebanyak 1\% (A) dan 2\% (B). Sebelum dicampur ke pakan, probiotik dilarutkan ke dalam putih telur sebagai binder sebanyak $2 \%$. Setelah itu probiotik dicampurkan ke dalam pakan dan diaduk hingga merata. Pencampuran pakan dengan probiotik Bacillus sp. dilakukan setiap hari selama pemeliharaan. Putih telur tetap diberikan pada perlakuan kontrol (K) tanpa pemberian probiotik. Pemeliharaan dilakukan selama 30 hari dengan frekuensi pemberian pakan tiga kali sehari (pukul 08.00, 15.00, dan 21.00 WIB).

\section{Perbanyakan bakteri $A$. hydrophila}

Bakteri yang diuji diregenerasi terlebih dahulu sebelum digunakan. A. hydrophila yang digunakan berasal dari Balai Riset Budidaya Perikanan Air Tawar Sempur, Bogor. Kultur primer diambil sebanyak satu ose untuk dibiakkan dalam cawan petri dan diinkubasi selama 24 jam pada suhu $28{ }^{\circ} \mathrm{C}$ dalam inkubator. Bakteri yang berumur 24 jam diambil sebanyak satu ose dan diinokulasikan ke dalam erlenmeyer yang berisi $25 \mathrm{~mL}$ media trypticase soy broth (TSB) dan diinkubasi selama 24 jam dalam inkubator bergoyang (water bath shaker) pada suhu $28{ }^{\circ} \mathrm{C}$ dengan kecepatan $140 \mathrm{rpm}$.

\section{Uji tantang}

Uji tantang dilakukan setelah pemeliharaan benih selama 30 hari. Benih ikan diambil sampel sebanyak sepuluh ekor dari kolam terpal dan dipindahkan ke akuarium berukuran $90 \times 50 \times 40 \mathrm{~cm}$. Saat uji tantang ditambahkan 
satu perlakuan yaitu kontrol positif $(\mathrm{K}+)$ sebagai pembanding ikan yang terinfeksi $A$. hydrophila dan tanpa pemberian probiotik. Penginfeksian A. hydrophila dilakukan pada setiap perlakuan, kecuali pada perlakuan kontrol negatif (K-) yang disuntikkan dengan larutan PBS, yang diinjeksi secara intramuskular pada hari ke-31. Benih lele diinjeksi bakteri $A$. hydrophila sebanyak $0,1 \mathrm{~mL} /$ ekor dengan kepadatan bakteri $10^{6} \mathrm{cfu} /$ mL. Selanjutnya dilakukan pemeliharaan dan pengamatan tingkat kelangsungan hidup benih ikan selama sepuluh hari.

\section{Parameter penelitian}

\section{Tingkat kelangsungan hidup}

Kelangsungan hidup ikan diamati pada akhir pemeliharaan dan setelah uji tantang. Perhitungan kelangsungan hidup dihitung berdasarkan persamaan:

$$
\mathrm{TKH}(\%)=\left(\sum \mathrm{Nt}\right) /\left(\sum \mathrm{No}\right) \times 100
$$

Keterangan :

$\mathrm{Nt}=$ jumlah ikan akhir (ekor)

No $=$ jumlah ikan awal (ekor)

\section{Laju pertumbuhan harian}

Laju pertumbuhan harian $(\alpha)$ dihitung dengan tahapan bobot ikan ditimbang saat awal dan akhir pemeliharaan kemudian dihitung bobot rataratanya. Perhitungan laju pertumbuhan harian ikan dilakukan menggunakan rumus:

$$
\alpha(\%)=(\sqrt{ }(\mathrm{Wt} / \mathrm{Wo})-1) \times 100
$$

$$
\begin{aligned}
& \text { Keterangan : } \\
& \begin{aligned}
\alpha \quad= & \text { laju pertumbuhan harian }(\%) \\
\mathrm{Wt}= & \text { bobot rata-rata ikan pada akhir } \\
& \text { pemeliharaan }(\mathrm{g}) \\
\mathrm{Wo}= & \text { bobot rata-rata ikan pada awal } \\
& \text { pemeliharaan }(\mathrm{g}) \\
\mathrm{t} \quad & \text { periode pengamatan (hari) }
\end{aligned}
\end{aligned}
$$

\section{Konversi pakan}

Konversi pakan selama pemeliharaan dihitung dengan mengunakan rumus:

$$
\mathrm{FCR}=\mathrm{F} /(\mathrm{Bt}+\mathrm{Bm}-\mathrm{Bo})
$$

\section{Keterangan:}

$$
\begin{aligned}
& \mathrm{FCR}=\text { konversi pakan } \\
& \mathrm{F} \quad=\text { jumlah pakan }(\mathrm{g}) \\
& \mathrm{Bt}
\end{aligned}
$$

$\begin{aligned} & \mathrm{Bm}= \text { biomassa ikan mati saat pemeliharaan } \\ &(\mathrm{g}) \\ & \mathrm{B} 0=\text { biomassa ikan pada awal pemeliharaan }\end{aligned}$ (g)

\section{Total eritrosit}

Darah diambil hingga skala 0,5 kemudian ditambahkan larutan Hayem's hingga mencapai skala 101. Kemudian digoyangkan seperti angka delapan selama 3-5 menit. Setelah itu dibuang satu tetes. Lalu darah diamati di mikroskop dengan perbesaran 100 kali. Kemudian hasil hitungan dimasukkan ke dalam rumus:

$$
\begin{aligned}
& \mathrm{SDM}\left(\mathrm{sel} / \mathrm{mm}^{3}\right)= \\
& \frac{\text { sel terhitung } \times \text { faktor pengencer }}{\text { volume kotak }}
\end{aligned}
$$

\section{Total leukosit}

Darah diambil hingga skala 0,5 kemudian ditambahkan larutan turk hingga mencapai skala 11. Kemudian digoyangkan seperti angka 8 selama 3-5 menit. Setelah itu dibuang satu tetes. Lalu darah diamati di mikroskop dengan perbesaran 400 kali. Kemudian hasil hitungan dimasukkan ke dalam rumus:

$$
\begin{aligned}
& \mathrm{SDP}\left(\mathrm{sel} / \mathrm{mm}^{3}\right)= \\
& \frac{\text { sel terhitung } \times \text { faktor pengencer }}{\text { volume kotak }}
\end{aligned}
$$

\section{Kadar hemoglobin}

Pengukuran kadar $\mathrm{Hb}$ menggunakan metode Sahli yang mengkonversikan darah kedalam bentuk asam hematin. Alat yang digunakan hemometer dan pipet sahli. Pertama darah dihisap dengan pipet sahli hingga skala $20 \mathrm{~mm}^{3}$. Lalu darah dipindahkan kedalam tabung Hb-meter yang telah diisi HCL 0,1 N. Lalu ditambahkan aquades hingga warna darah serupa dengan skala tabung sahli yang dilihat pada skala kuning.

\section{Kadar hematokrit}

Bahan yang digunakan crytoceal dan darah ikan uji. Tabung mikrohematokrit diisi darah hingga 3/4 bagian tabung. Ujung tabung ditutup menggunakan crytoceal. Tabung disentrifugasi dengan kecepatan $5.000 \mathrm{rpm}$ selama lima menit. Kadar hematokrit dihitung dengan rumus :

$$
\mathrm{Hc}(\%)=\mathrm{a} / \mathrm{b} \times 100
$$

Keterangan:

$\mathrm{Hc}=$ kadar hematokrit 
a = darah yang mengendap pada tabung

$\mathrm{b} \quad=$ panjang total volume darah pada tabung

\section{Analisis data}

Rancangan yang digunakan dalam penelitian ini yaitu rancangan acak lengkap (RAL) dengan empat perlakuan dan dua ulangan selama permeliharaan, kemudian empat perlakuan dan tiga ulangan setelah uji tantang. Data yang telah diperoleh kemudian ditabulasi menggunakan program Ms. Excel 2013 dan diuji menggunakan analisis ragam (ANOVA) dengan taraf kepercayaan 95\% menggunakan perangkat lunak Minitab 16. Perlakuan yang berbeda nyata dilanjutkan dengan uji lanjut Tukey's.

\section{HASIL DAN PEMBAHASAN}

\section{Hasil}

Kelangsungan hidup

Hasil pengamatan tingkat kelangsungan hidup ikan lele Clarias sp. sebelum dan setelah uji tantang dengan $A$. hydrophila disajikan pada
Gambar 1. Tingkat kelangsungan hidup sebelum uji tantang berkisar antara 88,75-97,68\% yang berbeda nyata pada perlakuan B terhadap perlakuan K-. Setelah uji tantang, kelangsungan hidup perlakuan K- dan B adalah 96,66\% dan $83,33 \%$ yang berbeda nyata dengan perlakuan $\mathrm{K}+$ sebesar $40 \%$.

\section{Laju pertumbuhan harian}

Nilai laju pertumbuhan harian (LPH) ikan lele pada akhir pemeliharaan disajikan pada Gambar 2. LPH selama pemeliharaan berkisar antara 4,39-5,40\%. LPH tertinggi diperoleh pada perlakuan B sebesar 5,40\% yang berbeda nyata dengan perlakuan $\mathrm{K}+$ sebesar 4,39\%. Namun perlakuan B, A, dan K- tidak berbeda nyata, sedangkan perlakuan A dan K- tidak berbeda nyata dengan $\mathrm{K}+$.

\section{Konversi pakan}

Konversi pakan ikan lele menunjukkan nilai yang berbeda nyata setelah pemeliharaan dan disajikan pada Gambar 3. Konversi pakan terkecil

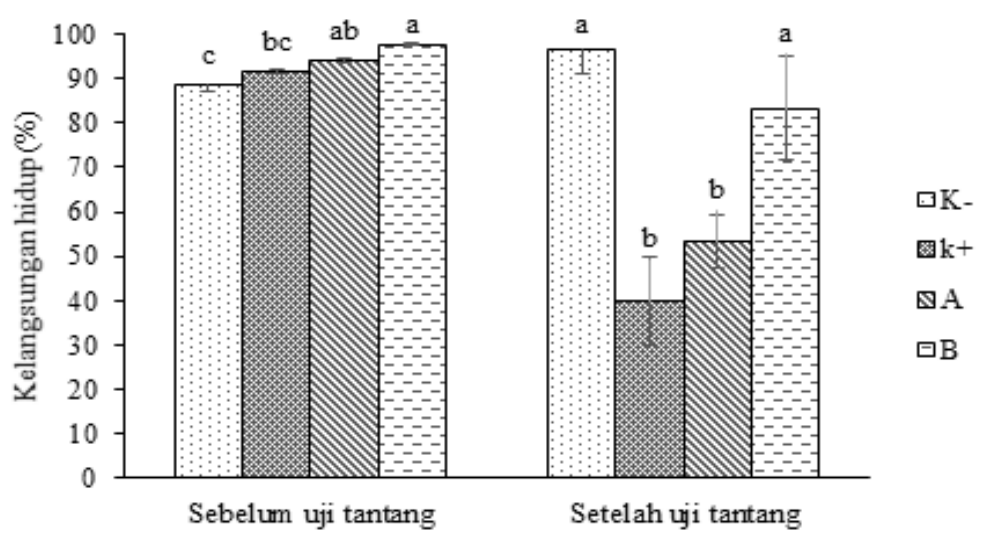

Gambar 1. Kelangsungan hidup sebelum uji tantang dan setelah uji tantang pada perlakuan pakan tanpa probiotik dan injeksi PBS (K-), pakan tanpa probiotik dan injeksi Aeromonas hydrophila $(\mathrm{K}+)$, pakan diberi probiotik $1 \%$ dan injeksi A. hydrophila (A), dan pakan diberi probiotik $2 \%$ dan injeksi A. hydrophila (B). Huruf yang berbeda di setiap bar menunjukkan adanya perbedaan antarperlakuan $(\mathrm{P}<0,05)$.

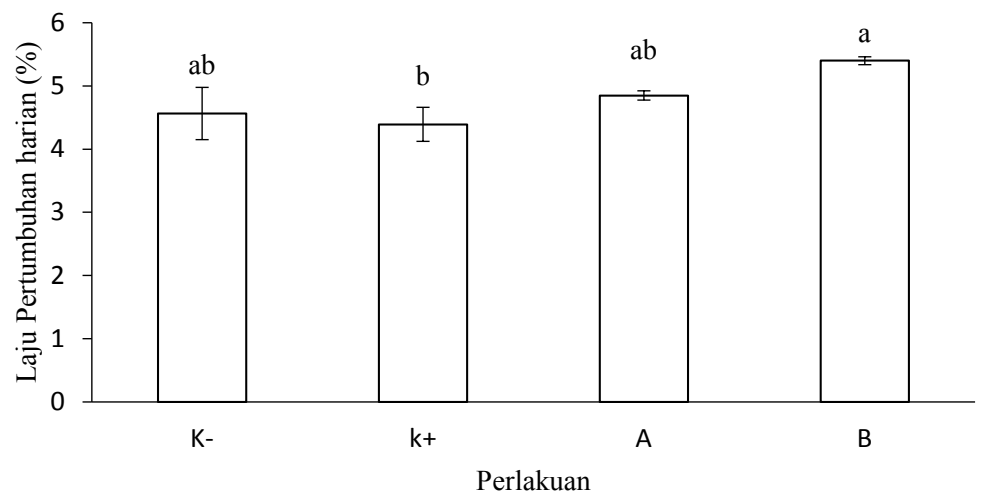

Gambar 2. Laju pertumbuhan harian selama pemeliharaan pada perlakuan pakan tanpa probiotik (K-), pakan tanpa probiotik (K+), pakan diberi probiotik 1\% (A), dan pakan diberi probiotik 2\% (B). Huruf yang berbeda di setiap bar menunjukkan adanya perbedaan antarperlakuan $(\mathrm{P}<0,05)$ 
diperoleh pada perlakuan B sebesar 0,75 yang tidak berbeda nyata dengan perlakuan A sebesar 0,94 . Namun berbeda nyata dengan perlakuan Ksebesar 1,13 .

\section{Total eritrosit}

Hasil pengukuran total eritrosit ikan lele disajikan pada Gambar 4. Total eritrosit pada awal pemeliharaan sebesar $0,69 \times 10^{6} \mathrm{sel} / \mathrm{mm}^{3}$ setiap perlakuan. Nilai total eritrosit hari ke-15 berkisar antara $1,34-1,40\left(\times 10^{6} \mathrm{sel} / \mathrm{mm}^{3}\right)$ yang tidak berbeda nyata pada setiap perlakuan. Nilai total eritrosit pada hari ke-30 pemeliharaan berkisar antara $1,37-1,91\left(\times 10^{6} \mathrm{sel} / \mathrm{mm}^{3}\right)$ yang berbeda nyata pada perlakuan B sebesar $1,91 \times 10^{6}$ $\mathrm{sel} / \mathrm{mm}^{3}$ terhadap setiap perlakuan. Setelah uji tantang, total eritrosit pada $\mathrm{K}+$ turun menjadi $0,63 \times 10^{6} \mathrm{sel} / \mathrm{mm}^{3}$ yang berbeda nyata terhadap perlakuan K- dan perlakuan B.

\section{Total leukosit}

Total leukosit ikan selama pemeliharaan dan setelah uji tantang disajikan pada Gambar 5. Total leukosit ikan lele pada awal pemeliharaan sebesar $0,74 \times 10^{4} \mathrm{sel} / \mathrm{mm}^{3}$ setiap perlakuan. Total leukosit hari ke-15 berkisar antara 1,15-2,05 $\left(\times 10^{4} \mathrm{sel} /\right.$ $\mathrm{mm})$. Total leukosit hari ke-30 berkisar antara $2,70-4,20\left(\times 10^{4} \mathrm{sel} / \mathrm{mm}^{3}\right)$ yang tidak berbeda nyata pada setiap perlakuan. Setelah uji tantang, total leukosit pada perlakuan $B$ naik menjadi $5,06 \times 10^{4} \mathrm{sel} / \mathrm{mm}^{3}$ yang berbeda nyata terhadap perlakuan K-.

\section{Kadar hemoglobin}

Kadar hemoglobin ikan lele pada awal pemeliharaan sebesar 5,60 g\% setiap perlakuan. Kadar hemoglobin hari ke-15 pada perlakuan B sebesar 8,80 g\% yang tidak berbeda nyata terhadap setiap perlakuan. Setelah uji tantang, kadar hemoglobin pada perlakuan K- 7,6 g\% dan perlakuan B 7,4 g\% berbeda nyata terhadap Perlakuan K+ 5,10 g\%. Kadar hemoglobin ikan lele ber disajikan pada Gambar 6 .

\section{Kadar hematokrit}

Hasil perhitungan kadar hematokrit disajikan pada Gambar 7. Kadar hematokrit ikan lele pada awal pemeliharaan sebesar $17,3 \%$ setiap perlakuan. Kadar hematokrit hari ke-15 pada perlakuan B sebesar 32,06\% yang berbeda nyata terhadap setiap perlakuan. Kadar hematokrit hari ke-30 berkisar 23,07-26,90\% yang tidak berbeda

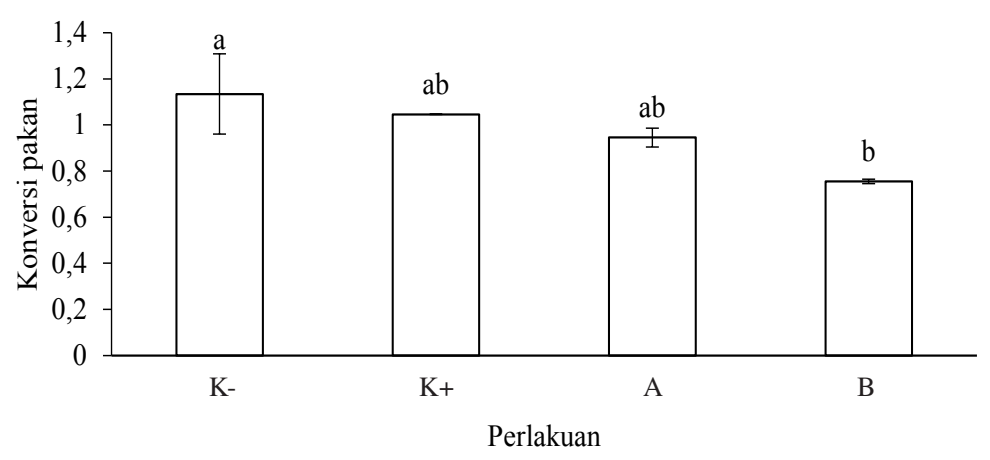

Gambar 3. Konversi pakan selama pemeliharaan pada perlakuan pakan tanpa probiotik (K-), pakan tanpa probiotik $(\mathrm{K}+)$, pakan diberi probiotik $1 \%(\mathrm{~A})$, dan pakan diberi probiotik $2 \%(\mathrm{~B})$. Huruf yang berbeda di setiap bar menunjukkan adanya perbedaan antarperlakuan $(\mathrm{P}<0,05)$

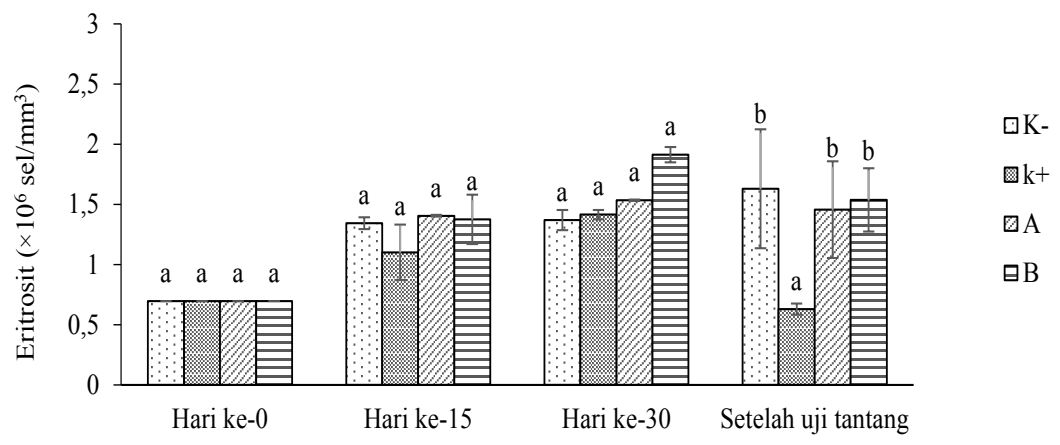

Gambar 4. Total eritrosit selama pemeliharaan hari ke-0, 15, 30, dan setelah uji tantang pada perlakuan pakan tanpa probiotik dan injeksi PBS (K-), pakan tanpa probiotik dan injeksi Aeromonas hydrophila $(\mathrm{K}+)$, pakan diberi probiotik $1 \%$ dan injeksi A. hydrophila (A), dan pakan diberi probiotik $2 \%$ dan injeksi A. hydrophila (B). Huruf yang berbeda di setiap bar pada hari yang sama menunjukkan adanya perbedaan antarperlakuan $(\mathrm{P}<0,05)$. 


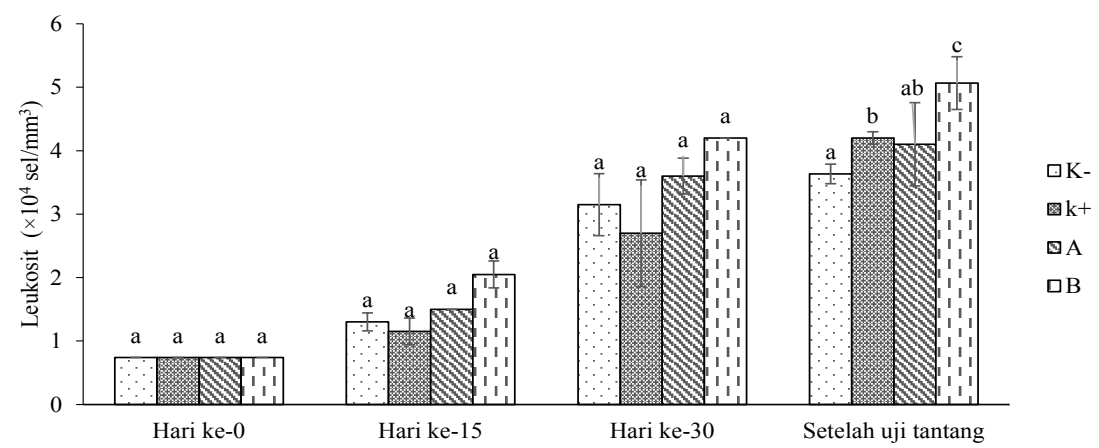

Gambar 5. Total leukosit selama pemeliharaan hari ke-0, 15, 30, dan setelah uji tantang pada perlakuan pakan tanpa probiotik dan injeksi PBS (K-), pakan tanpa probiotik dan injeksi Aeromonas hydrophila (K+), pakan diberi probiotik $1 \%$ dan injeksi A. hydrophila (A), dan pakan diberi probiotik $2 \%$ dan injeksi A. hydrophila (B). Huruf yang berbeda di setiap bar pada hari yang sama menunjukkan adanya perbedaan antarperlakuan $(\mathrm{P}<0,05)$.

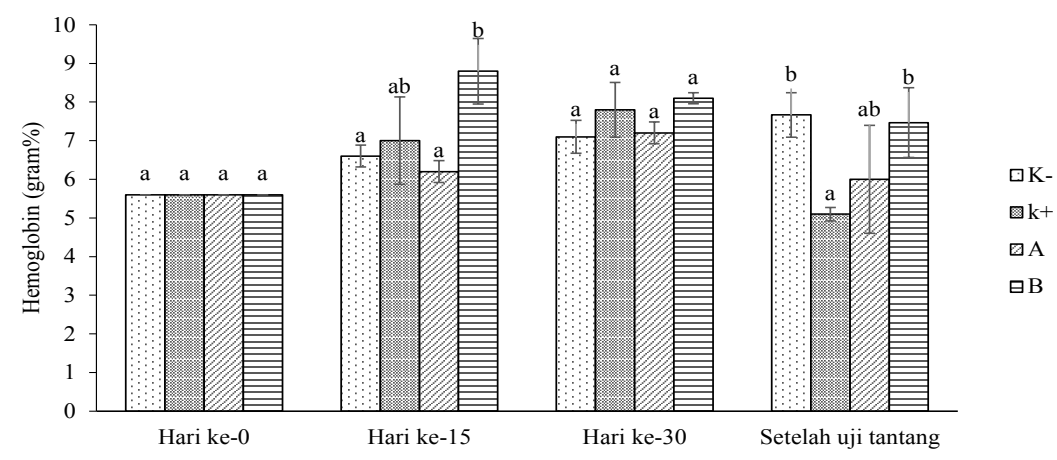

Gambar 6. Kadar hemoglobin selama pemeliharaan hari ke-0, 15, 30, dan setelah uji tantang pada perlakuan pakan tanpa probiotik dan injeksi PBS (K-), pakan tanpa probiotik dan injeksi Aeromonas hydrophila (K+), pakan diberi probiotik $1 \%$ dan injeksi $A$. hydrophila (A), dan pakan diberi probiotik $2 \%$ dan injeksi A. hydrophila (B). Huruf yang berbeda di setiap bar pada hari yang sama menunjukkan adanya perbedaan antarperlakuan $(\mathrm{P}<0,05)$.

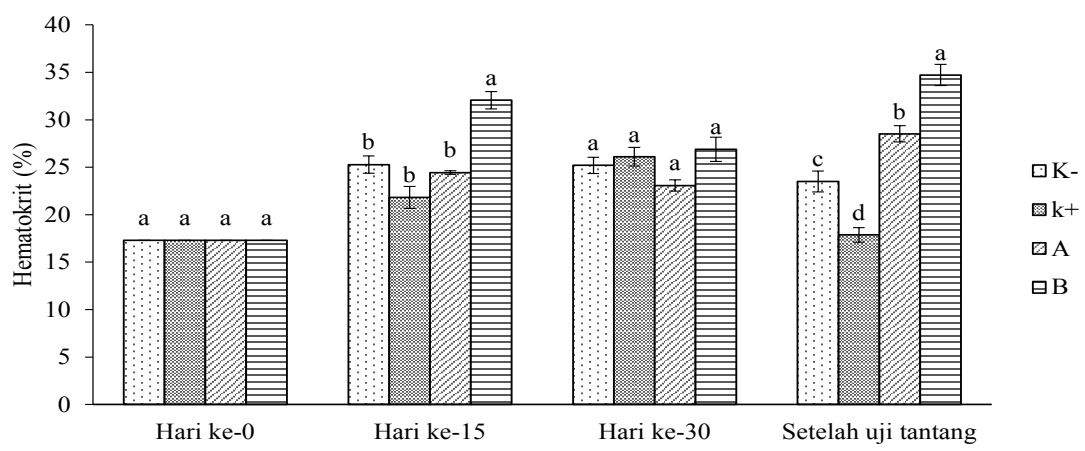

Gambar 7. Kadar hematokrit selama pemeliharaan hari ke-0, 15, 30, dan setelah uji tantang pada perlakuan pakan tanpa probiotik dan injeksi PBS (K-), pakan tanpa probiotik dan injeksi Aeromonas hydrophila $(\mathrm{K}+)$, pakan diberi probiotik $1 \%$ dan injeksi $A$. hydrophila (A), dan pakan diberi probiotik $2 \%$ dan injeksi A. hydrophila (B). Huruf yang berbeda di setiap bar pada hari yang sama menunjukkan adanya perbedaan antarperlakuan $(\mathrm{P}<0,05)$

nyata antarperlakuan. Setelah uji tantang, kadar hematokrit pada perlakuan B sebesar $34,71 \%$ berbeda nyata terhadap perlakuan lainnya.

\section{Pembahasan}

Hasil penelitian menunjukkan bahwa probiotik Bacillus sp. dapat meningkatkan laju pertumbuhan, konversi pakan, dan harian kelangsungan hidup setelah diinfeksi dengan
A. hydrophila. Dosis probiotik Bacillus sp. 2\% dapat meningkat laju pertumbuhan $83,33 \%$ secara signifikan lebih baik dari perlakuan lainnya. Selain itu, status kesehatan ikan berdasarkan gambaran darah ikan selama pemeliharaan dan setelah uji tantang juga lebih baik dari pada yang tidak diberi probiotik (kontrol).

Tingkat kelangsungan hidup ikan lele selama 30 hari pemeliharaan berkisar antara 88,75- 
$97,68 \%$ yang berbeda nyata yaitu pada perlakuan B (penambahan probiotik 2\%) sebesar 97,68\% terhadap perlakuan K- (tanpa penambahan probiotik) sebesar $88,75 \%$. Kelangsungan hidup saat uji tantang menunjukkan bahwa ikan lele yang diberi probiotik pada perlakuan B dengan nilai $83,33 \%$ menunjukkan hasil yang berbeda nyata terhadap perlakuan $\mathrm{K}+$ sebesar $40 \%$. Hal ini dikarenakan probiotik memiliki pengaruh terhadap komunitas mikroorganisme lingkungan usus dan memberikan keuntungan bagi inangnya (Balcazar et al., 2006). Menurut Rahmawan et al. (2014) bahwa pemberian probiotik dapat meningkatkan kelulushidupan pada ikan lele. Selain itu, pemberian probiotik dapat meningkatkan respons imun nonspesifik dan meningkatkan resistensi ikan terhadap serangan patogen (Widanarni et al., 2015; Tamamdusturi et al., 2016). Menurut Agustono et al. (2012), Bacillus sp. dapat memproduksi antibiotik untuk melawan Vibrio sp. pada ikan kerapu yang menitikberatkan pada efek multifaktor probiotik seperti produksi enzim, kompetisi nutrient, dan ruang sehingga meningkatkan tingkat kelangsungan hidup.

Nilai laju pertumbuhan harian ikan yang dipelihara selama 30 hari berkisar antara 4,39-5,40\%. Perlakuan B memiliki nilai LPH tertinggi dengan nilai $5,40 \%$ yang berbeda nyata dengan perlakuan $\mathrm{K}+$ sebesar $4,39 \%$. Hal ini dikarenakan probiotik yang diberikan pada ikan lele diduga meningkatkan populasi Bacillus sp. dalam usus ikan. Prinsip dasar kerja probiotik yaitu memanfaatkan kemampuan mikroorganisme dalam memecah rantai panjang karbohidrat, protein, dan lemak karena adanya enzim-enzim khusus yang dimiliki oleh mikroba untuk memecah ikatan tersebut (Hendrianto et al., 2009). Sehingga molekul kompleks yang masuk ke dalam usus diubah menjadi molekul sederhana yang akan mempermudah penyerapan oleh saluran pencernaan ikan.

Bakteri probiotik Bacillus sp. memiliki kemampuan mengekskresikan enzim protease, lipase, dan amilase. Enzim eksogenus tersebut dapat membantu enzim endogenus pada inang untuk menghidrolisis nutrien pakan sehingga meningkatkan ketersediaan nutrien yang siap diserap dari saluran pencernaan untuk masuk ke pembuluh darah untuk proses metabolisme selanjutnya (Widanarni et al., 2012).

Konversi pakan ikan lele setelah 30 hari pemeliharaan berkisar antara 0,75-1,13 . Perlakuan B memiliki nilai konversi pakan terkecil sebesar 0,75 yang berbeda nyata dengan perlakuan K- sebesar 1,13. Nilai konversi pakan dipengaruhi oleh protein pakan dan jumlah pakan yang diberikan. Hal ini dikarenakan nilai efisiensi pakan berkaitan dengan laju pertumbuhan. Semakin tinggi laju pertumbuhan maka semakin besar nilai efisiensi pakan yang didapat (Shafrudin et al., 2013). Penelitian ini menunjukan pemberian dosis probiotik dapat memberikan pengaruh yang nyata terhadap nilai konversi pakan. Hal ini dikarenakan adanya probiotik dalam usus yang diduga bekerja meningkatkan kandungan protein pakan dan membantu proses pencernaan. Hasil yang sama ditunjukan pada ikan trout yang diberi probiotik (Mohapatra et al., 2012).

Efektivitas pemberian probiotik melalui pakan terhadap respons imun ikan dapat diamati juga melalui gambaran darah. Parameter gambaran darah yang diamati meliputi kadar eritrosit (SDM), total leukosit (SDP), kadar hemoglobin $(\mathrm{Hb})$, dan kadar hematokrit $(\mathrm{Hc})$. Eritrosit merupakan salah satu indikator dari perubahan kondisi kesehatan ikan. Parameter gambaran darah telah digunakan sebagai indikator status kesehatan dibeberapa spesies ikan (Santos et al., 2009; Adedeji, 2010; Akinrotimi et al., 2012; Sayed \& Moneeb, 2015). Kadar eritrosit dari awal pemeliharaan hingga akhir pemelihaan berkisar antara $0,69-1,91\left(\times 10^{6} \mathrm{sel} / \mathrm{mm}^{3}\right)$. Nilai eritrosit pada perlakuan $\mathrm{B}$ memiliki kadar eritrosit sebesar $1,91 \times 10^{6} \mathrm{sel} / \mathrm{mm}^{3}$ yang berbeda nyata terhadap setiap perlakuan. Kadar eritrosit pada setiap perlakuan mengalami peningkatan selama pemeliharaan. Hal ini dikarenakan jumlah eritrosit dipengaruhi oleh kondisi nutrisi, aktivitas fisik, dan umur (Uribe et al., 2011). Setelah uji tantang, kadar eritrosit pada setiap perlakuan mengalami penurunan kecuali perlakuan K- yang tidak disuntik $A$. hydrophila. Kadar eritrosit terkecil diperoleh perlakuan $\mathrm{K}+$ sebesar $0,63 \times 10^{6}$ $\mathrm{sel} / \mathrm{mm}^{3}$ yang berbeda nyata terhadap setiap perlakuan. Hal ini diduga karena A. hydrophila mampu menghasilkan enzim eksotoksin, salah satunya hemolisin yang dapat melisiskan sel darah merah dan melepaskan hemoglobin dari sel darah (Triyaningsih et al., 2014). Hal ini juga yang menyebabkan pendarahan pada ikan dan menyebabkan kematian.

Total leukosit hari ke-30 berkisar antara $2,7-4,2\left(\times 10^{4} \mathrm{sel} / \mathrm{mm}^{3}\right)$. Setelah uji tantang setiap perlakuan mengalami peningkatan jumlah leukosit, sebagai upaya pertahanan tubuh ikan terhadap serangan patogen, yaitu bakteri A. hydrophila yang disuntikkan. Menurut 
Kurniawan et al. (2014) peningkatan jumlah sel leukosit diakibatkan adanya respons dari tubuh ikan terhadap infeksi penyakit. Sel leukosit berfungsi sebagai sel fagosit untuk mencegah bakteri yang tidak diinginkan dan menyebarkan faktor virulensi di dalam tubuh ikan.

Kadar hemoglobin $(\mathrm{Hb})$ dari awal hingga akhir pemeliharaan berkisar antara 5,6-8,80 g\%. Nilai hemoglobin yang didapat masih di dalam kisaran normal. Kadar hemoglobin hari ke-30 tetap meningkat yaitu berkisar antara 7,10-8,10 $\mathrm{g} \%$ yang tidak berbeda nyata terhadap setiap perlakuan. Setelah uji tantang, kadar hemoglobin berkisar antara 5,10-7,66 g\%. Pada perlakuan B sebesar 7,46 $\mathrm{g} \%$ berbeda nyata terhadap perlakuan $\mathrm{K}+$ sebesar 5,10 g\%. Kadar hemoglobin terkait dengan jumlah eritrosit, semakin rendah kadar eritrosit maka semakin rendah kadar hemoglobin (Royan et al., 2014). Fungsi dari hemoglobin adalah mengikat oksigen untuk proses katabolisme yang akan menghasilkan energi. Kadar hemoglobin rendah pada perlakuan $\mathrm{K}+$ diduga karena kadar eritrosit yang menurun akibat dari infeksi $A$. hydrophila

Kadar hematokrit pada awal pemeliharaan hingga akhir pemeliharaan berkisar antara 17,30$32,06 \%$. Setelah uji tantang kadar hematokit pada perlakuan B sebesar $34,71 \%$ yang berbeda nyata terhadap perlakuan $\mathrm{K}+$ sebesar $17,87 \%$. Rendahnya kadar hematokrit pada perlakuan $\mathrm{K}+$ diduga karena ikan mengalami anemia. Menurut Alamanda et al. (2007) rendahnya hematokrit merupakan salah satu indikator ikan mengalami anemia. Hal ini juga yang menyebabkan ikan menjadi stres dan menyebabkan kematian. Lalu kadar hematokrit pada perlakuan B mengalami peningkatan dengan nilai $34,71 \%$, $\mathrm{Hal}$ ini menunjukan pemberian probiotik mampu menstabilkan kadar hematokrit pada benih yang terinfeksi A. hydrophila.

\section{KESIMPULAN}

Ikan lele Clarias sp. yang diberi probiotik Bacillus sp. 2\% memperlihatkan kinerja probiotik terbaik dengan tingkat kelangsungan hidup setelah diinfeksi dengan $A$. hydrophila sebesar $83,33 \%$, laju pertumbuhan harian sebesar $5,40 \%$, dan konversi pakan 0,75 .

\section{DAFTAR PUSTAKA}

Adedeji OB. 2010. Acute effect of diazinon on blood plasma biochemistry in the African catfish Clarias gariepinus. Journal of Clinical Medicine and Research 2: 1-6.

Agustono, Syprapto H, Muhajir. 2012. Strategi bakteri probiotik untuk menekan pertumbuhan bakteri patogen didalam pencernaan kerapu Chromileptes altivelis dengan memproduksi beberapa bakterial substansi. Jurnal Ilmiah Perikanan dan Kelautan 4: 199-205.

Akinrotimi OA, Agokei EO, Aranyo AA. 2012. Changes in blood parameters of tilapiaguineensis exposed to different salinity levels. Journal of Environmental Engineering and Technology 1: 4-12.

Alamanda IE, Handajani NS, Budiharjo A. 2007. Penggunaan metode hematologi dan pengamatan endoparasit darah untuk penetapan kesehatan ikan lele dumbo Clarias gariepinus di kolam budidaya desa Mangkubumen Boyolali. Biodiversita 8: 3438.

Azhar F. 2013. Pengaruh probiotik dan prebiotik terhadap performan juvenile ikan kerapu bebek Comileptes altivelis. Buletin Veteriner Udayana 6: 1-9.

Balcázar JL, Blas ID, Ruiz-Zarzuela I, Cunningham D, Vendrell D, Múzquiz JL. 2006. The role of probiotics in aquaculture. Veterinary Microbiology 114: 173-186.

Cabello FC. 2006. Heavy use of prophylactic antibiotics in aquaculture: a growing problem for human and animal health and for environment. Enviromental Microbiology 8: 1131-1144.

[KKP]. 2014. Perikanan budidaya Indonesia. Direktorat Jendral Perikanan Budidaya. Kementerian Kelautan dan Perikanan. [Internet]. Diacu [2015 Februari 2]. Tersedia dari:http://www.djpb.kkp.go.id/berita.php? $\mathrm{id}=847$.

Kurniawan A, Sarjito, Prayitno SB. 2014. Pengaruh pemberian ekstrak daun binahong Anredera cordifolia pada pakan terhadap kelulushidupan dan profil darah lele dumbo Clarias gariepinus yang diinfeksi Aeromonas caviae. Journal of Aquaculture Management and Technology 3: 76-85.

Mohapatra, Chakraborty, Kumar V, Deboeck, Mohanta KN. 2012. Aquaculture and stress management: a review of probiotic intervention. Journal of Animal Physiology and Animal Nutrition 97: 405-430.

Putra AN, Widanarni, 2015. Screening of amylolytic bacteria as candidates of probiotics in tilapia Oreochromis sp. Research Journal of 
Microbiology 10: 1-13.

Royan F, Rejeki S, Haditomo C. 2014. Pengaruh salinitas yang berbeda terhadap profil darah ikan nila Oreochromis niloticus. Journal of Aquaculture Management and Technology 3: 109-117.

Santos AA, Ranzani-Paiva MJT, Veiga ML, Faustino L, Egami MI. 2009. Hematological parameters and phagocytic activity in fat snook Centropomus parallelus bred in captivity. Fish and Shellfish Immunology 33: 953-961.

Sayed AEH, Moneeb RH. 2015. Hematological and biochemical characters of monosex tilapia Oreochromis niloticus Linnaeus 1758 cultivated using methyltestosterone. The Journal of Basic and Applied Zoology 72: $36-42$.

Septiarini, Harpeni E, Wardiyanto. 2012. Pengaruh waktu pemberian probiotik terhadap respon imun nonspesifik ikan mas Cyprinus carpio yang diuji tantang dengan bakteri Aeromonas salmonicida. Jurnal Rekayasa dan Teknologi Budidaya Perairan 1: 39-46.

Setiawati JE, Tarsim, Adiputra YT, Hudaidah S. 2013. Pengaruh penambahan probiotik pada pakan dengan kelulushidupan, efisiensi pakan dan retensi protein ikan patin Pangasius hypophthalmus. Jurnal Rekayasa dan Teknologi Budidaya Perairan 1: 151-162.

Shafrudin D, Yuniarti, Setiawati M. 2013. Pengaruh penambahan probiotik pada pakan dengan dosis berbeda terhadap pertumbuhan, kelulushidupan, efisiensi pakan, dan retensi protein ikan patin Pangasius hypophthalamus. Jurnal Rekayasa dan Teknologi Budidaya Perairan 1:151-162.

Talpur AD, Munir MB, Mary A, Hashim R. 2014. Dietary probiotics and prebiotics improved food acceptability, growth performance, haematology and immunological parameters and disease resistance against Aeromonas hydrophila in snakehead Channa striata fingerlings. Aquaculture 426-427: 14-20.

Tamamdusturi R, Widanarni, Yuhana M.
2016. Administration of microencapsulated probiotic Bacillus sp. NP5 and prebiotic mannan oligosaccharide for prevention of Aeromonas hydrophila infection on Pangasianodon hypophthalmus. Journal of Fisheries and Aquatic Science. 11: 67-76

Triyaningsih, Sarjito, Prayinto B. 2014. Patogenisitas Aeromonas hydrophila yang diisolasi dari lele dumbo Clarias gariepinus yang berasal dari Boyolali. Journal of Aquaculture Management and Technology 3:11-17.

Uribe C, Folch H, Enriquez R, Moran G. 2011. Innate and adaptive immunity inteleost fish: a review. Veterinarni Medicina 5: 486-503.

Utami DAS, Widanarni, Suprayudi MA. 2015. Quality of dried Bacillus NP5 and its effecton growth performance of tilapia Oreochromis niloticus. Pakistan Journal of Biological Sciences 18: 88-93.

Widanarni, Sukenda, Setiawati M. 2008. Bakteri probiotik dalam budidaya udang: seleksi, mekanisme aksi, karakterisasi dan aplikasinya sebagai agen biokontrol. Jurnal Ilmu Pertanian Indonesia 13: 80-89.

Widanarni, Wahjuningrum D, Puspita F. 2012. Aplikasi bakteri probiotik melalui pakan buatan untuk meningkatkan kinerja pertumbuhan udang windu Penaeus monodon. Jurnal Sains Terapan 2: 32-49.

Yu HB, Rao PSS, Lee HC, Vilches S, Merino S, Tomas JM, Leung KY. 2004. A type III secretion system is required for Aeromonas hydrophila $\mathrm{AH}-1$ pathogenesis. Infection and Immunity 72: 1.248-1.256.

Zhang Q, Yu H, Tong T, Tong W, Dong L, Xu M, Wang Z, 2014. Dietary supplementationof Bacillus subtilis and fructooligosaccharide enhance the growth, non-specific immunity of juvenile ovate pompano Trachinotus ovatus and its disease resistance against Vibrio vulnificus. Fish and Shellfish Immunology 38: 7-14. 